\title{
Use assessment of electronic power sources for $\mathrm{SMAW}^{(\bullet)}$
}

\author{
A. $\operatorname{Scotti}^{(*)}$, M. Gomes ${ }^{(*)}$ y J. Pereira ${ }^{(* *)}$
}

\begin{abstract}
The aim of the present work was to assess the efficacy of the use of modern technologies for power supplies in Shielded Metal Arc Welding (SMAW). Coupon tests were welded by using a series of five different classes of commercial electrodes, covering their current ranges. Both a conventional electromagnetic and an electronic (inverter) power sources were employed. Fusion rate, deposition efficiency, bead finish and weld geometry were measured at each experiment. Current and voltage signals were acquired at a high rate to evaluate the dynamic behavior of the power sources. The static performances of both power sources were also determined. The results showed that despite the remarkable differences between the power supplies, based on static and dynamic characterizations, no significant difference was noticed in the operational behavior of the electrodes, in the given conditions, apart from a better anti-stick performance obtained with the electronic power source.
\end{abstract}

Keywords: Welding. SMAW. Coated electrodes. Power source.

\section{Evaluación del uso de fuentes electrónicas en la soldadura por SMAW}

\begin{abstract}
Resumen El objetivo del presente trabajo fue evaluar la eficacia del uso de tecnologías modernas para fuentes de energía en soldaduras con electrodo revestido (Shielded Metal Arc Welding - SMAW). Los materiales de ensayo se soldaron usando una serie de cinco clases diferentes de electrodos comerciales, cubriendo sus rangos de corriente. Para esto se utilizó una fuente de energía electromagnética convencional y una fuente de energía electrónica (inversora). La tasa de fusión, eficiencia de deposición, terminación del cordón así como el diseño de la soldadura se midieron en cada experimento. Las señales de corriente y voltaje se obtuvieron a una proporción alta para evaluar el comportamiento dinámico de las fuentes de energía. También se determinó la actuación estática de ambas fuentes. Los resultados mostraron que a pesar de las diferencias notables entre los suministros de energía, no se nota diferencia alguna significante en la conducta de trabajo de los electrodos, en las condiciones dadas, excepto en un mejor comportamiento del no pegado del electrodo, que se obtiene con la fuente de energía electrónica.
\end{abstract}

Palabras clave: Soldadura. SMAW. Electrodo revestido. Fuente de energía.

\section{INTRODUCTION}

The use of electronic power supplies has been growing since the last decade. However, this technology has been mostly applied either for processes of high productivity, such as the Gas Metal Arc Welding (GMAW), or processes more

(•) Trabajo recibido el día 20 de julio de 1998 y aceptado en su forma final el día 24 de marzo de 1999.

(*) Universidade Federal de Uberlândia. 38400-902, Uberlândia, MG - (Brasil).

(**) Universidade Federal do Ceará. 60455-760, Fortaleza, Ce (Brasil)

E-mail: jpf@truenet-ce.com.br quality demanding, as in the case of the Gas Tungsten Arc Welding (GTAW). The utilization of the so-called modern power sources for more popular processes, such as the Shielded Metal Arc Welding (SMAW), has shown a slower growth (usually as an option of multi-process equipment). The reason for this is likely related to a smaller capital investment required by this manual process.

However, some manufacturers have recently introduced a new concept of power sources dedicated to SMAW, based on the technology of inverters. This new equipment is claimed to be much lighter and smaller (portable) than its conventional counterpart (electromagnetic). It provides a faster control response as well. It is also 
more precise, since the current setting is independent of the arc characteristics (electrode type and arc length).

Irrespective of the real advantages pointed out, no work from the available literature was found trying to correlate these benefits with the weld performance. Therefore, a systematic investigation seemed desirable in order to obtain an actual picture of the effect of the electronic power supplies on the SMAW behavior. The methodology to be applied is to compare the performance of some types of electrodes under the action of different power supplies.

\section{EXPERIMENTAL PROCEDURE}

A series of five different classes of electrodes was taken, which main characteristics are listed in Table I. These electrodes were chosen due to the different operational behavior of each class, that is, distinct levels of difficulties for arc striking and maintenance.

Two DC power sources were employed. The first one, referred as inverter (INV), was a transistor controlled rectifier, light-weight, $200 \mathrm{~A}$ of nominal capacity at $35 \%$ working cycle, open circuit voltage of 53-75 V. The second power source was a conventional electromagnetic transformer-rectifier (CON), controlled by a movable-coil, with power capacity of $425 \mathrm{~A}$ at $30 \%$ working cycle, open circuit voltage of $90 \mathrm{~V}$. Before starting the experiments, the static characteristics of both power supplies were determined, as seen in figures 1 and 2 for three settings, using a variable resistor.

Then, bead-on-plate welds were carried out with each class of electrodes at two current levels (near the upper and the lower range values), in DCEP (direct current electrode positive), keeping the same travel speed $(25 \mathrm{~cm} / \mathrm{min})$ and an arc as short as possible. The strings used around $80 \%$ of the test plate length (200.38.9 mm - plain carbon steel). Each condition (paired electrode type-current) was

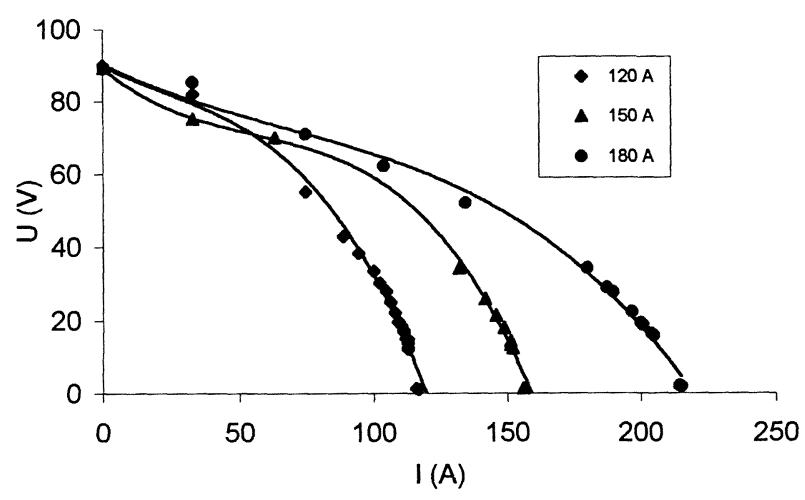

FIG. 1.- Static characteristic of the electromagnetic power source $(\mathrm{CON})$.

FIG. 1.- Característica estática de la fuente electromagnética (CON).

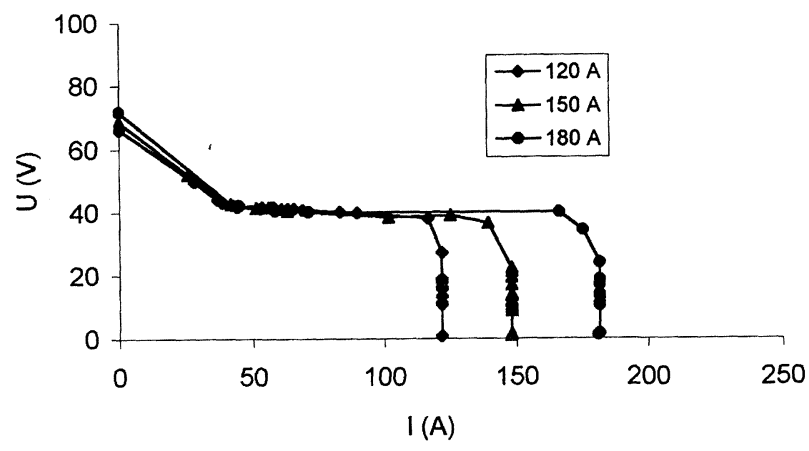

FIG. 2.- Static characteristic of the inverter power source (INV).

FIG. 2.- Característica estática de la fuente inversora (INV).

triplicated for better representation of the results. Since the objective was to compare power sources rather than electrodes, the use of an automatic welder simulator eliminated the human influence of the welders. This equipment keeps the same desired arc length regardless of the instantaneous fusion rate and plate geometric irregularities. The principle

TABLE I.- Characteristics of the electrodes used for assessing the power supplies

TABLA I.- Características de los electrodos usados para evaluar las fuentes de energía

\begin{tabular}{|c|l|c|c|}
\hline Denomination & \multicolumn{1}{|c|}{ Type } & $\begin{array}{c}\text { AWS class } \\
\text { range (A) }\end{array}$ & Current \\
\hline RUT & plain steel rutilic & E6013 & $100-200$ \\
CEL & plain steel cellulosic & E6010 & $80-180$ \\
BAS & plain steel basic & E7018 & $130-205$ \\
DUR & $3,5 \%$ Cr-0,1\%C hardfacing basic & E1-350 & $150-190$ \\
NOX & $19 / 10$ stainless steel rutilic & E-308-16 & $115-160$ \\
\hline
\end{tabular}


of automatic voltage control (AVC) was applied to the equipment design; a reference voltage controlled the arc length. The same procedure was applied for both the inverter and electromagnetic power supplies. Table II summarizes the welding parameters used.

Several criteria were proposed and used to compare both power sources. The first series of criteria concerned the operational aspects of the electrodes: fusion rate, deposition efficiency, bead finish and weld geometry. The two first ones were measured at each experiment by weighing each test plate and each electrode, before and after welding, and measuring the arc time. Bead finish and weld geometry (bead width and reinforcement) were assessed by visual analyses and linear measurements.

Other criteria used were related to the dynamic behavior of the paired electrode/power supplies. Current and voltage signals were acquired (data logger) at a high rate $(18 \mathrm{kHz}$ for $6 \mathrm{~s})$ during welding. A computer program, specially designed (1), treated the data and calculated several indices. The first index $\left(t_{\mathrm{t}}\right)$ measures the mean elapsed time of short-circuits, the second one $\left(t_{\mathrm{ct}}\right)$ measures the mean elapsed time of short circuits longer than 2 $\mathrm{ms}$, time in which it is expected to have metal transferred by short-circuiting (3). The third and fourth indices $\left(R t_{\mathrm{t}}\right.$ and $\left.R t_{\mathrm{ct}}\right)$ assess the regularity of the above mentioned times, that is, $R t_{\mathrm{t}}=\sigma / t_{\mathrm{t}}$ and $R t_{\mathrm{ct}}=\sigma / t_{\mathrm{ct}}$, where $\sigma$ is the standard deviation of the measured times.

A fifth and sixth indices $\left(T_{\mathrm{t}}\right.$ and $\left.T_{\mathrm{ct}}\right)$ indicate the periods (inversion of frequencies) of the occurrence of the short-circuiting, for any time length and for longer than 2-ms short-circuits respectively. Similarly, $R T_{\mathrm{t}}=\sigma / T_{\mathrm{t}}$ and $R T_{\mathrm{ct}}=\sigma / T_{\mathrm{ct}}$ manifest the regularity of the periods. Lastly, a ninth index (FE) tries to measure the magnitude and facility of charge transference (arc stability), by calculating

TABLE II.- Parameters (mean value and standard deviation) for test plate welding (travel speed $=25 \mathrm{~cm} / \mathrm{min}$ ), using the inverter and the conventional power supplies

Table II.- Parámetros (valor medio y desvio patrón) para la soldadura de chapas de ensayo (velocidad de soldadura $=25 \mathrm{~cm} / \mathrm{min}$ ), utilizando las fuentes inversora y convencional

\begin{tabular}{|c|c|c|c|c|}
\hline Denomination & $\begin{array}{l}\text { Power } \\
\text { source }\end{array}$ & $\begin{array}{l}\text { Mean and SD } \\
\text { of current } \\
\text { (A) }\end{array}$ & $\begin{array}{l}\text { Mean and SD of } \\
\text { voltage }(V)\end{array}$ & $\begin{array}{l}\text { Electrode Travel } \\
\text { Angle }(*)\end{array}$ \\
\hline RUT-Upper & $\begin{array}{l}\text { CON } \\
\text { INV }\end{array}$ & $\begin{array}{l}202.1 \pm 13.9 \\
198.2 \pm 19.1\end{array}$ & $\begin{array}{l}24.3 \pm 0.3 \\
22.9 \pm 0.4\end{array}$ & 0 \\
\hline RUT-Lower & $\begin{array}{l}\text { CON } \\
\text { INV }\end{array}$ & $\begin{array}{c}100.3 \pm 8.7 \\
100.4 \pm 12.3\end{array}$ & $\begin{array}{l}21.6 \pm 0.5 \\
22.4 \pm 0.5\end{array}$ & 0 \\
\hline CEL-Upper & $\begin{array}{l}\text { CON } \\
\text { INV }\end{array}$ & $\begin{array}{l}178.5 \pm 12.1 \\
175.1 \pm 13.2\end{array}$ & $\begin{array}{l}31.0 \pm 0.3 \\
29.2 \pm 0.3\end{array}$ & 11 \\
\hline CEL-Lower & $\begin{array}{l}\text { CON } \\
\text { INV }\end{array}$ & $\begin{array}{l}78.9 \pm 10.8 \\
81.0 \pm 15.0\end{array}$ & $\begin{array}{l}25.4 \pm 0.7 \\
24.7 \pm 0.5\end{array}$ & 11 \\
\hline BAS-Upper & $\begin{array}{l}\text { CON } \\
\text { INV }\end{array}$ & $\begin{array}{l}201.6 \pm 17.1 \\
196.4 \pm 24.3\end{array}$ & $\begin{array}{l}23.4 \pm 0.5 \\
24.1 \pm 0.5\end{array}$ & 11 \\
\hline BAS-Lower & $\begin{array}{l}\text { CON } \\
\text { INV }\end{array}$ & $\begin{array}{l}150.8 \pm 12.2 \\
149.6 \pm 19.7\end{array}$ & $\begin{array}{l}22.1 \pm 0.5 \\
22.3 \pm 0.5\end{array}$ & 0 \\
\hline DUR-Upper & $\begin{array}{l}\text { CON } \\
\text { INV }\end{array}$ & $\begin{array}{l}188.1 \pm 15.0 \\
186.1 \pm 18.8\end{array}$ & $\begin{array}{l}25.9 \pm 0.5 \\
23.7 \pm 0.5\end{array}$ & 0 \\
\hline DUR-Lower & $\begin{array}{l}\text { CON } \\
\text { INV }\end{array}$ & $\begin{array}{l}150.3 \pm 12.8 \\
149.5 \pm 18.5\end{array}$ & $\begin{array}{l}22.9 \pm 0.6 \\
23.1 \pm 0.5\end{array}$ & 0 \\
\hline NOX-Upper & $\begin{array}{l}\text { CON } \\
\text { INV }\end{array}$ & $\begin{array}{l}157.5 \pm 11.1 \\
154.8 \pm 12.5\end{array}$ & $\begin{array}{l}26.7 \pm 0.4 \\
26.9 \pm 0.5\end{array}$ & 11 \\
\hline NOX-Lower & $\begin{array}{l}\text { CON } \\
\text { INV }\end{array}$ & $\begin{array}{c}117.1 \pm 8.3 \\
117.8 \pm 10.6\end{array}$ & $\begin{array}{l}26.6 \pm 0.4 \\
26.0 \pm 0.4\end{array}$ & 11 \\
\hline
\end{tabular}

(*) Electrode Travel Angle equals 0 means that the electrode was perpendicular to the test plate, while +11 means an angle that the electrode was pointed backward to the welding direction. 
the electric power spent to reignite the arc after each short-circuiting (1). The regularity of this last index is defined by the tenth index, i.e., RFE = $\sigma / \mathrm{FE}$.

Finally, an exploratory test was performed to check the capability of each power source to refrain from sticking the electrode into the metal pool, if the arc became too short. Using a basic electrode (BAS), the reference voltage of the welder simulator controller was progressively decreased so that the electrode was forced into the weld pool. A CCD camera monitored the whole process.

\section{RESULTS}

Figures 3 and 4 illustrate the comparative results concerning fusion rates (FR) for the upper current and lower current limits, respectively. Similarly, figures 5 and 6 show the results with regard to the deposition efficiencies (DE). Due to a lack of space, the figures related to geometric parameters (bead width and reinforcement) are not shown in this paper. However, there is no remarkable geometric differences between the welds produced by the two power sources.

The results of the dynamic behavior of the power supplies under different electrode types are illustrated in figures $7,8,9$ and 10 , respectively for $t_{\mathrm{t}}$ and $t_{\mathrm{ct}}$ at upper current limits and $T_{\mathrm{t}}$ and $\mathrm{FE}$ at lower current limits. The choice of illustrating only these four results was by chance, since there is not enough room for all results. However, the tendency observed at a current level is maintained at the other level. In figure 8 only two classes are shown because the others did not present a significant number of longer than 2-ms short circuits.

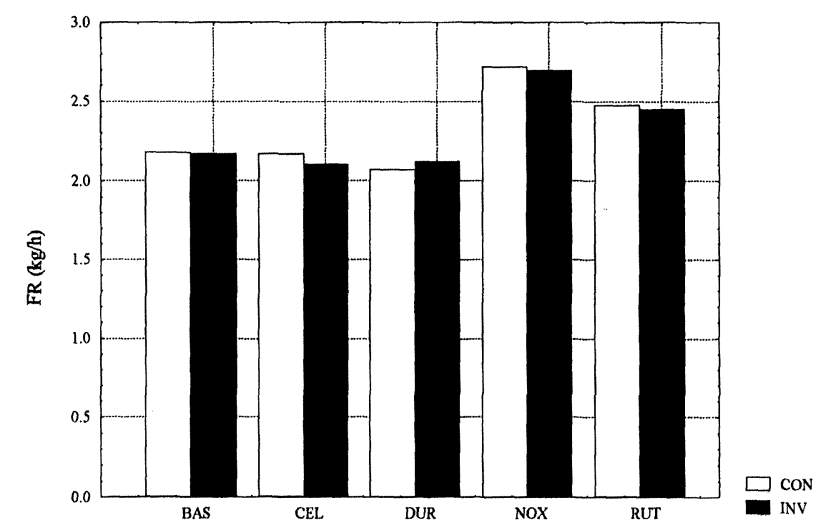

FIG. 3.- Fusion rate (FR) of different electrodes welded with the inverter and conventional sources, at upper current limits.

FIG. 3.- Tasa de fusión (FR) de diferentes electrodos soldados con las fuentes inversora y convencional en los límites superiores de corriente.

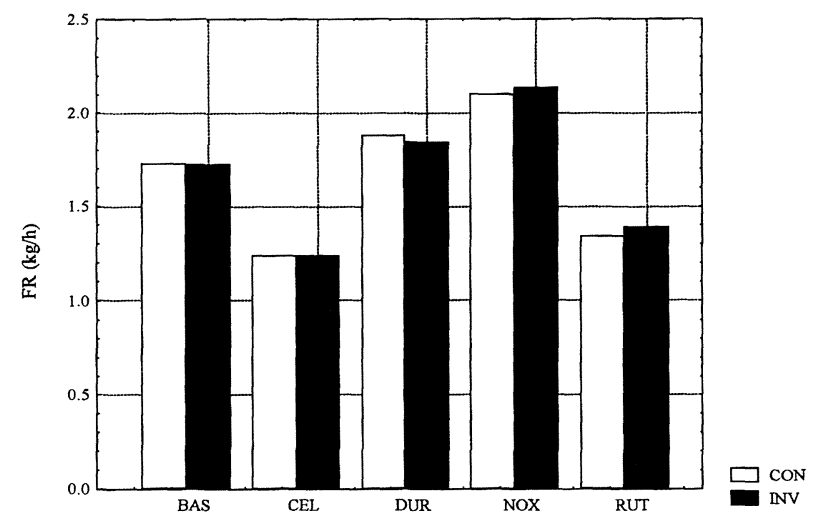

FIG. 4.- Fusion rate (FR) of different electrodes welded with the inverter and conventional sources, at lower current limits.

FIG. 4.- Tasa de fusión (FR) de diferentes electrodos soldados con las fuentes inversora y convencional en los límites inferiores de corriente.

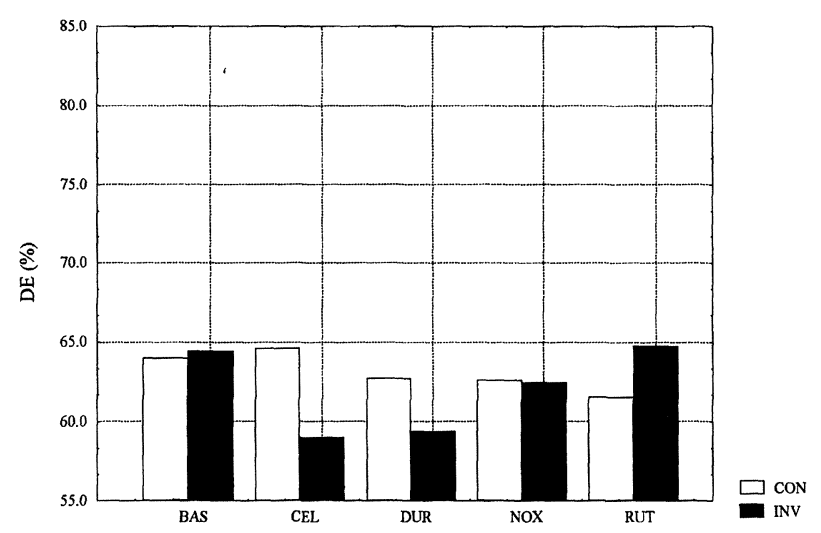

FIG. 5.- Deposition efficiency (DE) of different electrodes welded with the inverter and conventional sources, at upper current limits.

FIG. 5.-Eficiencia de deposición (DE) de los diferentes electrodos soldados con las fuentes inversora y convencional, en los límites superiores de corriente.

Finally, the test to check the anti-stick characteristic of the power sources showed that the inverter take more time for extinguishing the arc and to adhere to the bead, at the same welding conditions.

\section{DISCUSSION}

Figures 1 and 2 well characterize the main difference between both power sources. In the typical welding voltage range, the inverter showed a constant behavior of $V \times I$. This means that once the current is set, its static values do not change regardless the arc voltage. On the other hand, the 


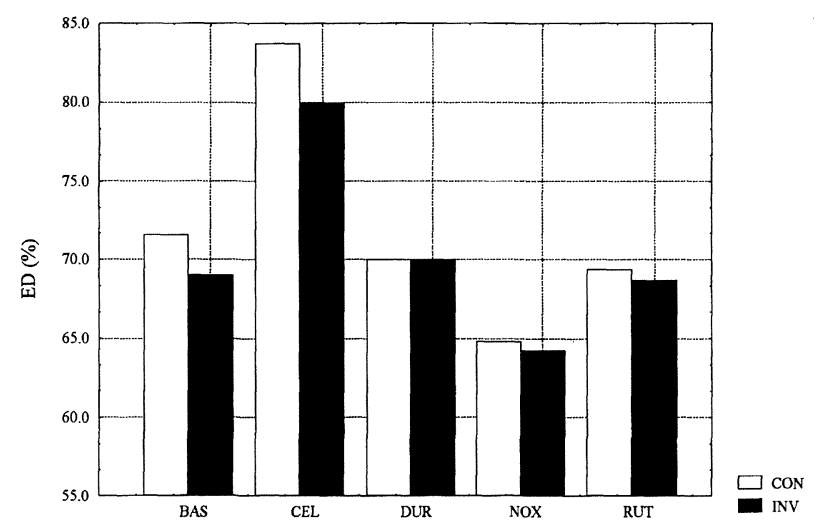

FIG. 6.- Deposition efficiency (DE) of different electrodes welded with the inverter and conventional sources, at lower current limits.

FIG. 6.-Eficiencia de deposición (DE) de los diferentes electrodos soldados con las fuentes inversora $y$ convencional, en los límites inferiores de corriente.

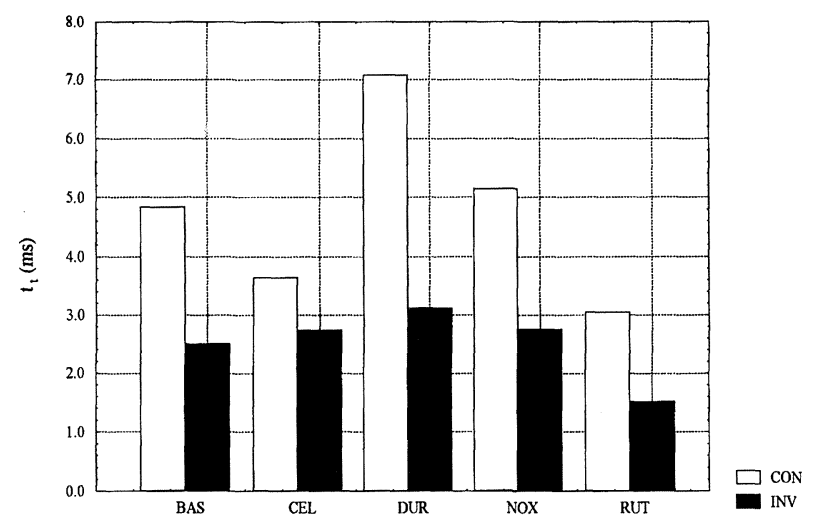

FIG. 7.- Mean elapsed time of short-circuiting $\left(t_{t}\right)$ for electrodes welded with the inverter and conventional sources, at lower current limits.

FIG. 7.- Tiempo medio transcurrido de cortocircuito $\left(\mathrm{t}_{\mathrm{t}}\right)$ para el electrodo soldado con las fuentes inversora y convencional, en los límites inferiores de corriente.

behavior of the conventional source is dependent on the voltage, which in turn, depends on the arc length and electrode type. Another difference was noticed when the anti-stick characteristics were assessed; the inverter showed better performance.

The differences seem to disappear when the comparison is made based on the operational behavior of the electrodes. As illustrated in figures 3 to 6 , one cannot disclose any superiority of one power supply over the other. To be more conscious about the results, a statistic $t$-test for hypotheses was applied on all results. This procedure estimates and tests the means and variances of two samples, so that one can statistically know if they are different

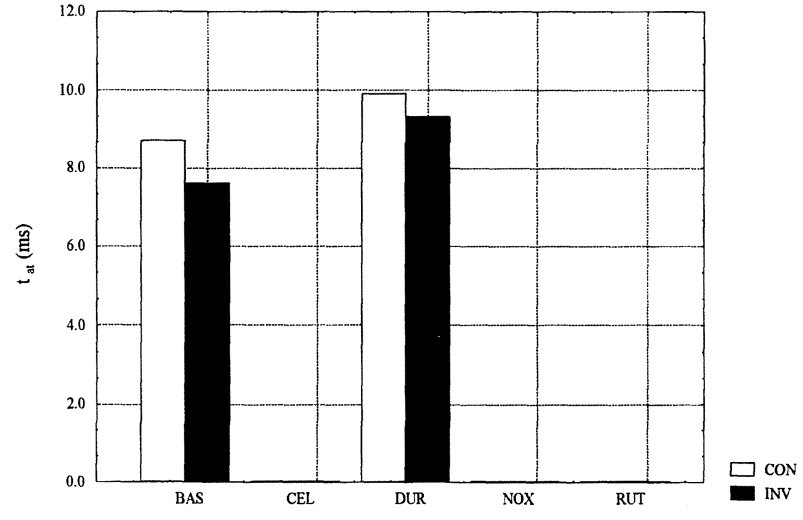

FIG. 8.- Mean longer than 2-ms elapsed time of short circuiting $\left(t_{c t}\right)$ for electrodes welded with the inverter and conventional sources, at upper current.

FIG. 8.- Tiempo medio transcurrido mayor que 2 ms de cortocircuito $\left(\mathrm{t}_{\mathrm{ct}}\right)$ para electrodos soldados con las fuentes inversora y convencional, en los límites superiores de corriente.

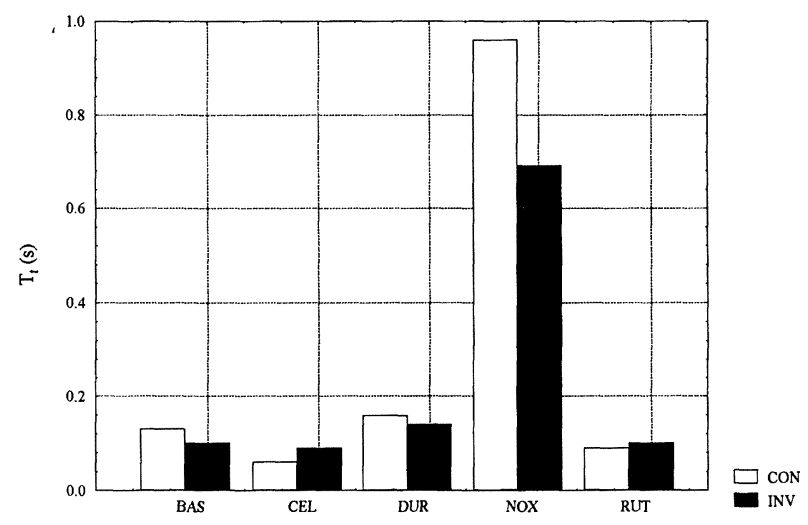

FIG. 9.- Period $\left(T_{\mathrm{t}}\right)$ between short-circuiting for different electrodes welded with the inverter and conventional sources, at lower current limits.

FIG. 9.- Períodos $\left(\mathrm{T}_{\mathrm{t}}\right)$ entre los cortocircuitos para diferentes electrodos soldados con las fuentes inversora y convencional, en los límites inferiores de corriente.

or not. The t-test showed undistinguishable results between the inverter and the conventional. The only exception was the deposition efficiency of cellulosic electrodes (CEL), which results showed to be higher for the conventional power supply at the two current levels (the difference, however, was only between 4 and $9 \%$ ).

Concerning the dynamic behavior, on the other hand, some differences were found. As seen in figures 7 and 8 , the short-circuiting elapsed times are much shorter for the inverter. This can be explained by its faster dynamic response and higher peak current during short-circuits. Figures 11 and 12 illustrate this characteristic through the plot of 


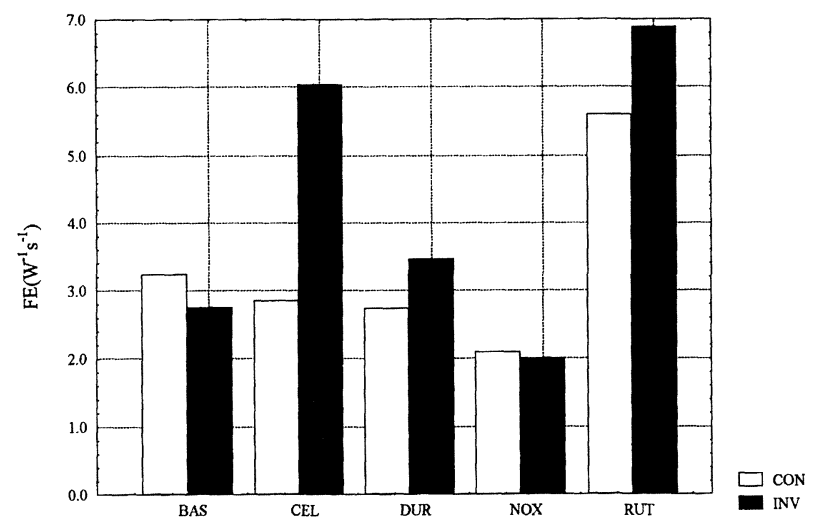

FIG. 10.- Facility of charge transfer (FE) of different electrodes welded with the inverter and conventional sources, at lower current limits.

FIG. 10. - Facilidad de transferencia de carga (FE) de los diferentes electrodos soldados con las fuentes inversora y convencional, en los límites inferiores de corriente.

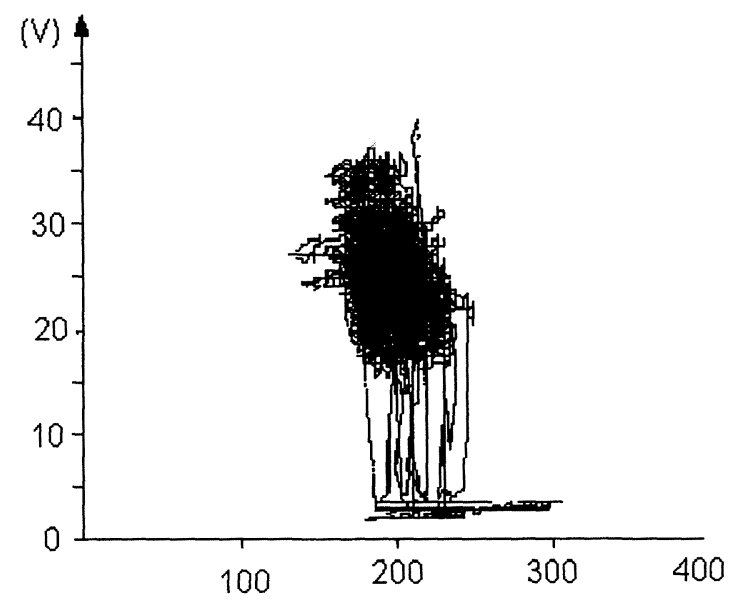

FIG. 11.- Dynamic characteristics (typical) of the conventional power source, welding with a basic electrode (BAS) at upper current limit.

FIG. 11.- Característica dinámica (típica) de la fuente convencional, soldando con electrodo básico $(B A S)$ en el límite superior de corriente.

the voltage versus the current; when the voltage drops (short-circuit), the current increases instantaneously.

Despite the fact that the inverter produces faster short-circuits, the number of them are statistically equal (Fig. 9) for all classes of electrodes, except for the NOX (actually, this exception did not happen in upper current limits, indicating that this result may be an outlier).

The above results may mean that the elapsed time has no great influence on the transfer It is possible to have stable transfer even if the time is not long enough to complete the transfer by shortcircuiting. This may also explain the reason for the

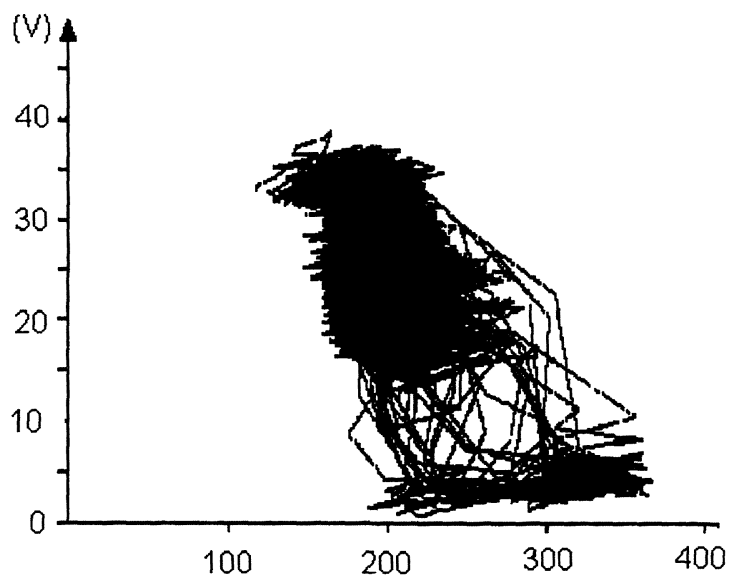

FIG. 12.- Dynamic characteristics (typical) of the inverter power source, welding with a basic electrode (BAS) at upper current limit.

FIG. 12.- Característica dinámica (típica) de la fuente inversora, soldando con electrodo básico $(B A S)$ en el límite superior de corriente.

lower deposition efficiency when welding with cellulosic electrodes; the slag effect, surface tension, is smaller in this case, not avoiding explosions during fast current increases. The higher peak current of the inverter would justify the better performance of the inverter concerning the antistick characteristic.

Finally, concerning the magnitude and facility of charge transfer (FE) (Fig. 10) there is no special advantage in favor of either inverter or conventional, despite the difference found amongst the classes. Larger FE presumably means more stable arc. If the two conditions (upper and lower current limits) are pooled and the $t$-test is applied, 3 results out of 10 present the inverter as the best, while only 2 other results point out the conventional. This index was intentionally proposed to study basic electrodes (1), and there is no evidence that it could also be applied to different electrode classes.

It is important to point out that the results might be quite different if other conditions (welding position and joint configuration, for instance) were used. Lower mean elapsed times of the shortcircuits $\left(t_{\mathrm{t}}\right)$ may probably make welding more difficult in overhead position, since gravity does not help metal transfer in this position.

\section{CONCLUSION}

Despite the remarkable difference between the power supplies, based on static and dynamic characterizations, no significant difference was noticed in the operational behavior of the 
electrodes, in the given conditions (electrode types, flat welding position, no groove joint). On this basis, it may be inferred that there is no difference in the operational weld performance if a conventional power supply is exchanged for an electronic one. However, in addition to its portability, the inverter showed a better anti-stick characteristic. This is important for not easily weldable electrodes, such as E7018. Metallurgical effect was not verified.

\section{Acknowledgements}

The help of ESAB Ind. Com. SA, Brazil, in providing equipment and consumable is greatly appreciated. The work would not have been done without this collaboration. Thanks are also expressed to the Brazilian council for research development, CNPq/PADCT, for the financial support.

\section{REFERENCES}

1) Farias, J.P., Metallic Magnesium as Coating Component for Welding with C-Mn-Ni Electrodes, PhD Thesis, UFSC, Brazil, 1993, 224 p. (in Portuguese)

2) Pokhodnya, I.K., Gorpenyuk, V.N., Milichenko, S.S., Pomonarev, V.E., Starodubtsev, L.V., ShCVachKa, V.I. y YAVDOSHChIN, I.R. Metallurgy of Welding - Vol 1: Arc Processes and Electrode Melting, Riecansky Science Publishing, UK, 1990, 246 p. 